\title{
Systèmes techniques, éthique sociale et idéologie
}

\section{Marceau Gast}

\section{OpenEdition}

\section{Journals}

Édition électronique

URL : https://journals.openedition.org/tc/1028

DOI : $10.4000 /$ tc. 1028

ISSN : 1952-420X

\section{Éditeur}

Éditions de l'EHESS

\section{Édition imprimée}

Date de publication : 1 septembre 1983

ISSN : 0248-6016

\section{Référence électronique}

Marceau Gast, « Systèmes techniques, éthique sociale et idéologie », Techniques \& Culture [En ligne], 2 | 1983, mis en ligne le 26 janvier 2006, consulté le 29 septembre 2022. URL : http:// journals.openedition.org/tc/1028; DOI : https://doi.org/10.4000/tc.1028

Ce document a été généré automatiquement le 29 septembre 2022.

Tous droits réservés 
Systèmes techniques, éthique sociale et idéologie

\author{
Marceau Gast
}

